\title{
The Neighbour, The Carer and The Old Friend - the complex world of testamentary capacity
}

\author{
Juliet Brook*
}

The relationships made by people in their later years are complex and as a result so are the wills the elderly make. Perhaps children have moved away and a bond has grown between the testator and their long term friend and carer. Perhaps a neighbour has become, over the years, more like family than those with whom they share a blood tie. ${ }^{1}$ For these reasons and many others, solicitors are asked to make wills for clients in the last years of their life that break the expectation that the wealth of the older generation will benefit the younger. ${ }^{2}$

Solicitors are reporting a rise in contentious probate litigation ${ }^{3}$ and the Law Commission has turned its attention to this issue and will examine it in its forthcoming Wills Project which has a stated aim of reducing 'the likelihood of wills being challenged after death, and the incidence of litigation'. ${ }^{4}$

Whatever the reasons, the distress cause when "family" is disinherited by an elderly testator can have expensive consequences and lead to long-lasting rifts within families. This paper will explore why so many challenges are made to the validity of wills, in particular on the grounds of lack of capacity, and examine whether it is possible to create a simpler, more workable test for capacity that will also provide the protections necessary to preserve the autonomy of often vulnerable testators.

The first part of this paper will explore the current definition of testamentary capacity and the means by which the testator's lack of capacity is determined. The second part will examine our obligations to those with impaired capacity under the UN Convention on the Rights of Persons with Disabilities. The third part will examine why there are so many legal challenges to wills, before the final part analyses the difference between capacity and autonomy and considers the inherent difficulties with any simple, singular notion of capacity.

\section{Part 1 - Outline of the problem, capacity and presumptions}

\footnotetext{
* Senior Lecturer at the University of Portsmouth. Many thanks to Greg Osborne and Caroline Cox and to the anonymous peer reviewer for their comments on an earlier draft.

${ }^{1}$ Examples of such changing relationships can be seen in Cowderoy v Cranfield [2011] EWHC 1616 (Ch D), [2011] WTLR 1699 and Cattermole v Prisk [2006] 1 FLR 693 (Ch D).

${ }^{2}$ Whilst only about half of the population describe themselves as "likely" to inherit, of those who thought they were "very likely" or "definite" to inherit, 91\% expect to inherit from their parents - see K Rowlington and S McKay, Attitudes to Inheritance in Britain (Joseph Rowntree Foundation, 2005) Ch 2.

${ }^{3}$ Whilst court statistics only reflect those cases with sufficient merit to lead to formal court action, these statistics reflect the rise in instructions received by probate solicitors. See for example http://www.independent.co.uk/news/uk/home-news/where-theres-a-will-family-feuds-lead-to-700-increasein-high-court-disputes-in-five-years-8475962.html.

${ }^{4}$ http://www.lawcom.gov.uk/project/wills/.
} 
A will is seen as an ambulatory document that can be revoked at any time prior to the death of the testator. ${ }^{5}$ The testator therefore remains free to change his or her mind, with the will only becoming fixed and unalterable on the testator's death. Until that time, the beneficiaries' potential inheritance is a mere hope - the 'spes successionis'. Furthermore in England ${ }^{6}$ it is accepted that the testator has had testamentary freedom for five hundred years. ${ }^{7}$ Our common law tradition has none of the 'forced heirship' rules of the kind that exist in many European countries. ${ }^{8}$ There are some exceptions to this principle, the most useful of which (as far as disappointed relatives are concerned) is the Inheritance (Provision for Family and Dependants) Act 1975. This enables certain specified categories of persons (for example the testator's cohabitee) to make a claim for 'reasonable financial provision $^{\prime 9}$ if the testator's will or intestacy has not provided for them adequately. However, there are strict rules on who can claim under this legislation and even a successful claimant will only be awarded 'reasonable financial provision', which may still be far less than they were expecting. In particular, despite the success of the daughter in llott $v$ Mitson ${ }^{10}$ claims by financially independent adult children usually fail.

Other exceptions to the principles of testamentary freedom appear through doctrines such as mutual wills, proprietary estoppel, and constructive trusts, but these are beyond the scope of this paper and will not be discussed further.

If none of these claims are available the disappointed relative may decide to challenge the will itself. Such challenges will either be made because there was a previous will under which they stood to inherit more, or because they will gain under the intestacy provisions. As an example, let us consider Keith and David. Keith (40) is the sole child of David (73). Keith's mother died 10 years ago. Under the terms of a previous will, Keith is David's sole heir. However, David has becomes increasingly reliant on Isla (58), a neighbour who provides help and companionship to him. Keith does not get on with Isla, and this has led to rows between him and his father. Following one of these rows David makes a new will leaving only a small pecuniary legacy to Keith, and leaving the residue to Isla. David tells his solicitor that this is because Keith has received plenty of help from him in his lifetime, and David is keen to thank Isla (who has little money herself) for her care. Keith is a successful businessman, so a claim under the Inheritance (Provision for Family and Dependants) Act

\footnotetext{
${ }^{5}$ Halsbury's Laws 5th edn (2010) vol 102, para 2.

${ }^{6} \mathrm{~A}$ reference to England includes a reference to Wales.

${ }^{7}$ Roger Kerridge, Parry \& Kerridge: The Law of Succession, 13th edn (London, Sweet \& Maxwell, 2016$) 183$.

${ }^{8}$ Law Commission, Intestacy and Family Provision Claims on Death (Law Comm No. 331, 2011) para 1.21 where the idea of forced heirship was described as "alien to our legal tradition".

${ }^{9}$ Inheritance (Provision for Family and Dependants) Act 1975, s1.

10 Ilott v Mitson [2011] EWCA Civ 346, [2012] 2 FLR 170 (CA).
} 
1975 would be fruitless. However, if Keith can show that the new will in favour of Isla is invalid for any reason, Keith will inherit under the old will. Even if there was no prior will, as David's only child (unless David re-marries) Keith will inherit on intestacy. This family situation is far from unusual; if you factor in the large increases in house prices seen by the baby-boomer generation and the likelihood of step-families it becomes more understandable why contentious probate claims have increased. Although the spes successionis does not give any title to property, nor any right to sue for property, it is the tension between the testamentary freedom of the testator and the perceived entitlements of the relatives that is usually the root cause of litigation.

A will is invalid if it does not comply with at least one of the three fundamental requirements for validity, namely testamentary intention, the testator must have capacity, and the formalities set out in the Wills Act $1837^{11}$ need to be complied with. Some challenges are made on the grounds of failure to comply with formalities, but these are relatively few in number. Instead most challenges are either on the grounds of lack of intention (that the testator did not intend to make that particular will, and therefore did not know and approve of the contents of the will) or lack of capacity. Both claims often incorporate an implicit allegation that the testator was persuaded to make the new will by the new beneficiary, yet to establish either claim there is no need to show any form of undue influence. ${ }^{12}$ The substantive allegation is instead that the terms of the new will demonstrate that the testator was so susceptible to suggestions that they lacked sufficient capacity to make a will that reflected their own volition. Challenging a will on the grounds of lack of capacity instead of undue influence may also seem more acceptable to the litigants, who will usually already be very well acquainted with each other.

In stark contrast to most civil litigation, in contentious probate the key witness is always dead, so there is no opportunity for the court to assess capacity directly through the court process. The most acrimonious of these cases are not those where the testator has clearly lost capacity, nor are they the ones where there can be no real doubt cast upon their capacity at all. Instead, it is the borderline cases that are ripe for litigation, and where the difficulties for families and solicitors alike arise and it is these cases that are the main focus of this paper.

\section{The Common Law Test for Capacity}

\footnotetext{
11 Wills Act 1837, s 9.

${ }^{12}$ Claims are rarely made on the grounds of fraud or undue influence in England, not least because the burden of proof is on the challenger. See also Kerridge, The Law of Succession 77-78 and 85-90.
} 
The test for capacity was originally set out in Banks $v$ Goodfellow ${ }^{13}$, the key elements of which are that the testator must:

a) understand the nature of his act (of making a will) and its effects;

b) understand the broad extent of the property in his estate;

c) be able to comprehend and appreciate the claims to which he ought to give effect; and

d) that no disorder of his mind 'shall poison his affections, pervert his sense of right, or his will in disposing of his property'

It was recently confirmed ${ }^{14}$ that this remains the test for testamentary capacity, despite the introduction of the Mental Capacity Act 2005. This is due to the fact that the provisions of the Mental Capacity Act 2005 are to define the circumstances in which living people can and cannot make decisions for themselves ${ }^{15}$ and the provisions of that act 'are inapt to describe a process of evaluating whether a past decision of a deceased person was one which he had capacity to take'. ${ }^{16}$ There are a number of consequences of this distinction but the primary one is that, whilst the MCA 2005 raises a presumption of capacity, there is no such presumption of testamentary capacity. Instead, the initial burden of proof in proving a will lies with the propounder (the person who seeks to admit the will to probate), and this will be discussed further below. As a result probate solicitors will ensure, as long as there is time available, that they comply with the 'Golden Rule' from Kenward $v$ Adams. ${ }^{17}$ This rule specifies that whenever there are instructions by a testator whose capacity could be called into question, either due to their age or ill health, the will should be approved or witnessed by a medical practitioner. The record of the medical practitioner's examination of the testator will then stand as evidence of the testator's capacity if required in the future. More pertinently, the existence of such a certificate should dissuade any potential claimants from commencing litigation. ${ }^{18}$

The other differences between the common law and statutory capacity tests are more subtle, but it is arguable that they result in a lower test for capacity than that prescribed by the MCA 2005 . The first of these, identified by Nicholas Strauss QC, is that the MCA 2005 requires a person to be able to understand all the information relevant to the making of a decision. In particular, they must be able

\footnotetext{
${ }^{13}$ Banks v Goodfellow (1869-70) LR 5 QB 549, [1861-73] All ER Rep 47 (QB).

${ }^{14}$ Re Walker (Deceased) [2014] EWHC 71 (Ch D), [2015] WTLR 493. Whilst this has not yet been approved at Appeal Court level, this paper will not challenge this decision.

${ }^{15}$ Explanatory notes to the Mental Capacity Act 2005 (MCA 2005), para 4.

${ }^{16}$ Re Walker (Deceased) (n 14) [27].

${ }^{17}$ Kenward $v$ Adams The Times, November 291975 (Ch D).

${ }^{18}$ See Re Key (Deceased) [2010] EWHC 408 (Ch D), [2010] 1 WLR 2020 [8] for judicial comment on the merits of complying with the golden rule.
} 
to retain that information, and use or weigh that information as part of the process of making the decision. ${ }^{19}$ In contrast the Banks $v$ Goodfellow test does not require the ability to remember and understand all the relevant information, and in Simon $v$ Byford, Lewison $L J$ rejected any capacity test that would amount to no more than a test of the memory. ${ }^{20}$

Secondly, in the view of Nicholas Strauss QC, if the MCA 2005 was the test for testamentary capacity then the effect of s3(1) together with s 3(4) would be that a testator would lack capacity if he was unable to understand or weigh information as to the consequences of the choices. ${ }^{21}$ In contrast in Simon $v$ Byford Lewison $\mathrm{L}$ noted that there is only a requirement for the testator to understand the direct consequences of their actions; there is no need for a full understanding of the collateral consequences. ${ }^{22}$

The fact that the common law capacity test seems to set the bar lower than the MCA 2005 capacity test has been noted with approval ${ }^{23}$ as it ensures that adults with impaired capacity retain their autonomy. This fits with the general ethos of encouraging people to make wills and therefore avoid the risk of intestacy. Whilst the Court of Protection has the ability to make a statutory will for those lacking testamentary capacity, ${ }^{24}$ any such statutory will would only ever be a 'best interests' decision ${ }^{25}$ instead of the true will of the testator. The existence of two separate capacity tests could result in some people retaining testamentary capacity yet falling within the remit of the MCA 2005 but this was not considered to be problematical. ${ }^{26}$

The general principle that the autonomy of a testator should be preserved for as long as possible is demonstrated in various ways throughout the case law on this subject. For example, the principle in Parker v Felgate ${ }^{27}$ enables a testator with quite severe dementia to still have mental capacity if they know that the will they are signing has been drafted in accordance with instructions they gave to a solicitor when they had capacity, even if they are no longer able to remember those instructions. Similarly a testator who would, in other contexts, be held to have lost capacity may still make a will if

\footnotetext{
${ }^{19}$ MCA 2005 ss 3(1)(b) and (c).

${ }^{20}$ Simon v Byford [2014] EWCA Civ 280, [2014] WTLR 1097 [39], [40] (CA).

${ }^{21}$ Re Walker (Deceased) (n 14) [24].

22 Simon v Byford ( $\mathrm{n}$ 20) [45]. In this case, the collateral consequences could only be understood if the testator could recall not just the extent of her own shareholding in the family company, but also the extent of that of her son.

${ }^{23}$ Re Walker (Deceased) (n 14) [32].

${ }^{24}$ MCA 2005, ss 16 and 18.

25 ibid, s 1(5).

${ }^{26}$ Re Walker (Deceased) (n 14) [35].

27 Parker v Felgate (1883) 8 PD 171, applied recently in Perrins v Holland [2010] EWCA Civ 840, [2011] Ch 270 (CA).
} 
they have 'lucid intervals', and the will is made during one such period. ${ }^{28}$ These exceptions ensure that the testator has as great an opportunity as possible for self-determination, thereby escaping the need for a distribution in accordance with the 'blunt instrument' ${ }^{29}$ of intestacy. As noted in Gill $v$ Woodall, 'if the court sets aside a will, the result will be either that an earlier will prevails or that the rules of intestacy apply: either eventuality may result in an outcome that appears to comply with the wishes of the testatrix even less than that produced by the will at issue'.$^{30}$

Yet the fact remains that elderly testators can be particularly vulnerable and susceptible to the influence of others. The reality of many situations is that the age of the testator has left them socially dependent on a smaller circle of acquaintances and that, coupled with an increasing lack of confidence arising from physical decline and some occasional confusion can lead to a 'grey zone'. ${ }^{31}$

The conclusion of Cockburn CJ in Banks v Goodfellow is particularly striking:

The English law leaves everything to the unfettered discretion of the testator, on the assumption that, though in some instances, caprice, or passion, or the power of new ties, or artful contrivance, or sinister influence, may lead to the neglect of claims that ought to be attended to, yet, the instincts, affections, and common sentiments of mankind may be safely trusted to secure, on the whole, a better disposition of the property of the dead, and one more accurately adjusted to the requirements of each particular case, than could be obtained through a distribution prescribed by the stereotyped and inflexible rules of a general law. ${ }^{32}$

Thus the courts have long been aware of the dilemma that everything that preserves the autonomy of the testator will also place the testator at risk of becoming a victim of 'artful contrivance or sinister influence'. In order to try to protect vulnerable testators the common law response has resulted in a complex set of presumptions and counter-presumptions, to determine the validity of a will as follows:

1. The burden of proof is initially on the propounder, i.e. the person seeking to admit the will to probate. However, the principle of 'omnia praesumuntur rite esse acta' comes into play, if the will is duly executed and appears rational on its face, capacity is presumed.

\footnotetext{
${ }^{28}$ See, for example, Banks v Goodfellow (n 13) but also earlier cases such as Cartwright v Cartwright (1793) 1 Phill. 90, 161 ER 923 (KB).

${ }^{29} \mathrm{http}: / /$ www.lawcom.gov.uk/project/wills/.

${ }^{30}$ Gill v Woodall [2010] EWCA Civ 1430, [2011] Ch 380 [26] (CA).

${ }^{31}$ M. I. Hall, 'Equity Theory: Responding to the Material Exploitation' in I Doron (ed) Theories on Law and Ageing: The Jurisprudence of Elder Law (Springer-Verlag, 2009).

${ }^{32}$ Banks v Goodfellow (n 13) 564.
} 
2. The burden of proof will then pass to the challenger who will need to adduce evidence to raise a real doubt as to the testator's lack of capacity. If there is no history of mental illness this will be hard to do and the new will would then be admitted to probate. However, for many elderly testators there are signs of the onset of dementia, no matter how slight. There may have been instances where they were seen to be forgetful, and possibly losing some of their faculties. The more severe these symptoms are, the more likely it is that a real doubt as to capacity can be demonstrated.

3. If sufficient evidence of lack of capacity can be brought forward the burden of proof will pass back to the propounder to establish capacity. This is often an extremely difficult burden to discharge, as the key witness is dead and the evidence that has already been brought before the court raises questions that are hard to dispel. ${ }^{33}$

From this it can be seen that the starting point is not an investigation into the capacity of the testator but consideration of the terms of the will itself. If we consider David and Keith once more, our father and son whose brief family history was set out earlier, the new will must be examined for rationality. On the facts, a will such as David's new will appears to have a rational explanation (Keith is well off, Isla has little money, Keith and David are increasingly estranged) so a presumption of testamentary capacity will be raised and Keith would need to produce evidence to raise a real doubt as to David's lack of capacity. It can be extremely hard to disprove capacity, especially if the testator was still managing their own affairs in other aspects of their life. If there has been a recent assessment of the testator's capacity (or, better still, if the Golden Rule mentioned above has been followed) it will be nearly impossible for Keith to bring a successful challenge. In contrast, if David has a history of declining mental health then it will be easy for Keith to raise the doubt as to David's lack of capacity. At this point the burden of proof would pass back to Isla who would need to prove capacity - an equally difficult task once real doubt has been raised.

\section{The Rationality of the Will}

The significance of the rationality of the will had been explained prior to Banks v Goodfellow (in the context of lucid intervals) as follows:

Now I think the strongest and best proof...is that which arises from the act itself; that I look upon as the thing to be first examined, and if it can be proved and established that it is a rational act rationally done the whole case is proved. What can you do more to establish the act? because, suppose you are able to shew the party did that which appears to be a rational

\footnotetext{
${ }^{33}$ This evidential sequence was neatly summarised by Briggs J in Re Key (Deceased) (n 18) [97].
} 
act, and it is his own act entirely, nothing is left to presumption in order to prove a lucid interval. Here is the rational act rationally done. In my apprehension, where you are able completely to establish that, the law does not require you to go further. ${ }^{34}$

Therefore for over two hundred years the courts have used the rationality of a will as a check and counter-balance to ensure the autonomy of the testator. Whilst it could be argued that this would enable the courts to impose their own view of what the testator ought to have done there is little evidence in the case law of this occurring. There are passages from the judgment in Banks $v$ Goodfellow that indicate a clear link in Cockburn CJ's mind between 'rationality' and theories of natural law, for example when as he discusses 'a moral responsibility of no ordinary importance' which goes alongside the freedom of testamentary disposition, ${ }^{35}$ but his judgment goes on to emphasise that there are other considerations at play, and suggested that this is at the heart of why England does not have any form of forced heirship law. He explained that the testator's nearest relatives were not the only people to have claims on the estate, and that some relatives may be more in need than others. There is therefore neither a need for the beneficiaries to be limited to close relatives, nor was there a need to treat all children equally. ${ }^{36}$

Despite the principle of testamentary freedom most testators follow a predictable path, with relatives being the main beneficiaries ${ }^{37}$ and studies have also shown that most testators do treat relatives of equal genetic 'rank' equally. ${ }^{38}$ However the courts strive not to be prescriptive in their definition of 'rational', emphasising that a rational will is one that distributes property to those whom the testator feels have an entitlement to some of his estate, whether relatives or not, and taking into account their need. ${ }^{39}$

Whilst rationality is a starting point for admitting a will to probate it is not sufficient to prove capacity; the decision that a will is rational merely raises a presumption of capacity. A recent exposition of this principle was in Re Key (Deceased) ${ }^{40}$ in which a fresh will executed within a week of the death of the testator's wife of 65 years was held to be 'eminently rational' due to its fair (i.e. equal) treatment of the testator's children. ${ }^{41}$ Despite this finding sufficient doubt was raised as to

\footnotetext{
${ }^{34}$ Cartwright v Cartwright (n 28), 927 (Sir William Wynne).

${ }^{35}$ Banks v Goodfellow (n 13) 563.

${ }^{36}$ ibid, 564.

37 Jonathan Herring, Older People in Law and Society (Oxford, Oxford University Press, 2009) 314.

$38 \mathrm{~J}$ Finch and J Mason, Passing On: Kinship and Inheritance in England (Routledge, 2000) 77.

${ }^{39}$ See Cattermole v Prisk (n 1), Markou v Goodwin [2013] EWHC 4570 (Ch D), [2014] WTLR 605 and Re Watson (Probate), sub nom Carr v Beaven [2008] EWHC 2582 (Ch D) for examples of dispositions that may be seen as contrary to expectations yet were held to be eminently rational.

${ }^{40}$ Re Key (Deceased) (n 18).

${ }^{41}$ ibid [99] (Briggs J).
} 
the capacity of the testator and this transferred the burden to the propounders to prove capacity, which they were unable to do. The will was therefore successfully challenged.

Conversely even if a will is seen to be irrational, that does not necessarily mean that it will be successfully challenged. It has often been stated that there is no need for a testator to leave his estate in a particular way, and no obligation for him to give effect to the moral claims on his estate. ${ }^{42}$ Under the Banks $v$ Goodfellow test the testator must simply know and understand the claims, even if he subsequently ignores them. As May $L$ stated in Sharp v Adam 'An irrational, unjust and unfair will must be upheld if the testator had the capacity to make a rational, just and fair one'.$^{43}$ Notwithstanding this, the resulting shift in the burden of proof on to the propounder to prove capacity does mean that there are few cases where clearly irrational or capricious wills are successfully upheld. ${ }^{44}$ Although rationality must not be used as a pretext for ensuring that the testator makes the 'right' will, and thereby restricting testamentary freedom, if no reason or justification can be discerned for the terms of the will it seems understandable that the court is likely to find that the testator lacked capacity;

the ultimate question before the court, when assessing testamentary capacity, is not whether the will is a fair one in all the circumstances of the case. On the other hand, if the provisions of a will are surprising, that may be material to the court's assessment of whether the testator did have capacity. ${ }^{45}$

It should be noted that this test is not dissimilar to the MCA 2005 capacity requirements; whilst s 1(4) states that 'A person is not to be treated as unable to make a decision merely because he makes an unwise decision', the use of the word 'merely' indicates that particularly strange decisions can be used alongside other evidence to conclude that a person lacks capacity. ${ }^{46}$

\section{Part II - The UN Convention on the Rights of Persons with Disabilities and the Capacity / Autonomy Distinction}

The absence of a presumption of testamentary capacity can be criticised, especially now we have a clear statutory presumption of capacity in other contexts through the MCA 2005. Article 12 of the

\footnotetext{
${ }^{42}$ See, eg Gill v Woodall ( $\mathrm{n} 30$ ) [26]: '[A] court should be very slow to find that a will does not represent the genuine wishes of the testatrix simply because its terms are surprising, inconsistent with what she said during her lifetime, unfair, or even vindictive or perverse' (Lord Neuberger MR), although note that in this case the will was found to be invalid because the testatrix did not know and approve its contents.

${ }^{43}$ Sharp v Adam [2006] EWCA Civ 449, [2006] WTLR 1059 (CA) [79].

${ }^{44}$ But see Cowderoy v Cranfield (n 1) [145] where a "surprising" will was upheld and Parker v Litchfield [2014] EWHC 1799 (Ch D) [34] where a will that could be understood as "not fair" was upheld.

${ }^{45}$ Cowderoy v Cranfield (n 1) [133] (Morgan J).

${ }^{46}$ Jonathan Herring, Older People in Law and Society 56 and see also Re B (Consent to Treatment: Capacity) [2002] EWHC 429, [2002] 2 All ER 449 (F).
} 
UN Convention on the Rights of Persons with Disabilities (CRPD) requires states to recognise the equal legal capacity of those with disabilities, and to take appropriate measures to provide access for persons with disabilities to the support they may require in exercising their legal capacity. ${ }^{47}$ The Committee on the Rights of Persons with Disabilities clarified these 'capacity recognition' requirements by general comment ${ }^{48}$ in which the overarching principles of the Convention (namely individual autonomy and the freedom to make one's own choices) was emphasised. ${ }^{49}$ Furthermore it was noted in the comment that there has been a failure by states to understand that compliance with Article 12 requires 'a shift from the substitute decision-making paradigm to one that is based on supported decision-making'. ${ }^{50}$

It has been discussed elsewhere ${ }^{51}$ whether the provisions of the MCA 2005 comply sufficiently with the CRPD's requirement to move away from the concept of substituted decision making, although the MCA 2005 does clearly require the testator to participate in the decision so far as possible. ${ }^{52}$ However, there is a difference between those testators who have clearly lost capacity and for whom the only solution is a statutory will, and those who have a borderline testamentary capacity. It is the wills of these latter testators that are the focus of this paper; these are the subjects of most of the litigation, and by the time the will is discovered it is usually too late to apply to the Court of Protection for a statutory will. ${ }^{53}$ As Lord Cranworth noted in Boyse $v$ Rossborough, 'There is no possibility of mistaking midnight for noon, but at what precise moment twilight becomes darkness is hard to determine'. ${ }^{54}$

The provisions of the MCA 2005 only apply once the testator has lost capacity ${ }^{55}$ but the inherent expense and delays involved in an application to the Court of Protection mean that it is better for all if the testator can be helped to make their own will whilst they still have a residual amount of capacity. As noted above there will be testators for whom a statutory will would be possible but who would still satisfy the Banks $v$ Goodfellow test sufficiently to execute their own valid will, especially if the terms of their will are relatively straight-forward, and compliance with the CRPD

\footnotetext{
${ }^{47}$ Convention on the Rights of Persons with Disabilities (adopted 13 December 2006, entered into force 3 May 2008) 2515 UNTS Article 12(2), 12(3).

${ }^{48}$ Committee on the Rights of People with Disabilities (2014) General Comment No 1 on Article 12: Equal recognition before the law $\mathrm{CRPD} / \mathrm{C} / \mathrm{GC} / 1$.

${ }^{49}$ ibid [4].

50 ibid [3].

${ }^{51}$ Rosie Harding 'The Rise of Statutory Wills and the Limits of Best Interests Decision-Making in Inheritance' (2015) 78(6) MLR 945.

${ }^{52}$ MCA 2005, s 4(4).

${ }^{53}$ See, eg Re Key (Deceased) (n 18) in which the sons had taken steps towards the appointment of a receiver by the Court of Protection once they discovered the presence of a new will.

${ }^{54}$ Boyse v Rossborough [1857] 10 ER 1192 (HL) 1210.

${ }^{55}$ MCA 2005, s 16.
} 
requires the preservation of these individuals' right to make their own will for as long as possible. Indeed, the Committee on the CRPD is critical of the type of functional approach to capacity that is contained within the MCA 2005 whereby once mental capacity is lost, the corresponding legal capacity is immediately denied. Instead, the Committee argue that support should be provided in exercise of legal capacity ${ }^{56}$ and the existence of principles such as the rule in Parker $v$ Felgate go some way towards meeting this criticism.

It could be argued that the best way to ensure compliance with the CRPD would be to introduce a presumption of capacity, along the lines of that set out in the MCA 2005, to ensure that only those who have clearly lost capacity need to resort to the Court of Protection. However whilst this might provide certainty and could enable those with degenerative cognitive diseases to retain testamentary capacity for longer this would not assuage the criticisms of the functional approach to capacity, nor would it enhance supported decision-making.

However, there is a further danger inherent in such a presumption, namely that we would not comply adequately with paragraph 4 of the CRPD that requires states to

ensure that all measures that relate to the exercise of legal capacity provide for appropriate and effective safeguards to prevent abuse in accordance with international human rights law. Such safeguards shall ensure that measures relating to the exercise of legal capacity respect the rights, will and preferences of the person, are free of conflict of interest and undue influence, are proportional and tailored to the person's circumstances

This could be called the 'protectionist' requirement, as it is noted in the general comment on paragraph 4 that there may be increased risks of undue influence for those who rely on the support of others, and therefore safeguards for the exercise of legal capacity must include protection against undue influence. ${ }^{57}$ Yet despite the CRPD's recognition of this risk, the protection offered by states must also 'respect the rights, will and preferences of the person, including the right to take risks and make mistakes'. ${ }^{58}$

Therefore compliance with the CRPD requires states to enable the individual with impaired capacity to be self-determining for as long as possible through supported decision-making, yet at the same time requires sufficient safeguards against undue influence. The complexity of this requirement supports the view that any simple presumption of capacity would exacerbate the risks of testators

\footnotetext{
${ }^{56} \mathrm{n} 48$ above [15].

57 ibid [22].

58 ibid [22].
} 
succumbing to the influences of others, and this would remove the autonomy that the CRPD strives to protect.

Whilst debates about capacity and autonomy arise in many areas of law, ${ }^{59}$ in the opinion of the author probate is an area where the legal response to impaired capacity must be particularly astute to the risks of external influences, and therefore the second 'protectionist' part of the CRPD requirement must receive greater weight than in other contexts. The fact that a constant close companionship can alter the testator's evaluation of family relationships has long been recognised; as Erskine J noted in Harwood v Baker:

[T]he protection of the law is in no cases more needed, than it is in those where the mind has been too much enfeebled to comprehend more objects than one, and most especially where that one object may be so forced upon the attention of the invalid, as to shut out all others that might require consideration. ${ }^{60}$

To understand why there should be additional considerations about the vulnerability of elderly testators it is necessary to explore (briefly) the basic ideas of property ownership.

\section{Part III - Theories of Property}

Most theories of property are devised in order to support and justify the notion of private ownership of property. Early Greek philosophers such as Plato and Aristotle (and their predecessors) debated whether private ownership and accumulation of property was justified at all, but the starting point for modern theories of property ownership is, for many, seen as Locke's justification: 'every man has a property in his own person; this nobody has any right to but himself. The labour of his body...are properly his'. ${ }^{61}$

Locke viewed property as a god-given right, but later theorists assimilated the ownership of property with the establishment of law. For example, Hume was an advocate of the utilitarian approach to the state, and argued that property ownership was both useful and beneficial as it encourages industry. Bentham emphasised that '[p]roperty and law are born together, and die together. Before laws were made there was no property; take away laws and property ceases' ${ }^{62}$

\footnotetext{
${ }^{59}$ For example in relation to medical care, where the question arises whether a patient has sufficient capacity to consent to or refuse treatment.

${ }^{60}$ Harwood v Baker (1840) 13 ER 117, 3 Moo PC 282 (PC) 290.

${ }^{61}$ John Locke, The Second Treatise of Government Ch V [27] (John Locke, Two Treatises of Government (CreateSpace Independent Publishing Platform 2016) 86).

62 Jeremy Bentham, Principles of the Civil Code Part I Ch VIII (Jeremy Bentham, Theory of Legislation: Translated from the French of Etienne Dumont by R. Hildreth (Adamant Media Corporation, 2005) 112-3.
} 
Whilst there remains on-going debate about the nature of property rights ${ }^{63}$ it is relatively well accepted that property rights, and ownership of property is 'a power relationship - a relationship of social and legal legitimacy existing between a person and a valued resource' ${ }^{64}$ The complexity of this relationship is demonstrated by the 'bundle of rights' theories of property, and such theories are helpful to justify interventionist legislation such as the Inheritance (Provision for Family and Dependants) Act 1975.

Whilst there is not space within this paper for a detailed analysis of property theories, the relevance of these ideas to ownership of property on death should become immediately obvious. Hume stated that property produced or improved by man's art or industry 'ought also to descend to children and relations for the same useful purpose ${ }^{65}$ - the notion that the creator of the value should be able to control its destination was seen as a beneficial by-product of property law, and of course the default intestacy provisions rank children second only to the spouse or civil partner of the deceased.

The protection that the law gives to property rights also enables us to plan for future use of our own property without interference from the state. Bentham suggested that 'the idea of property consists in an established expectation'. ${ }^{66}$ He continued '[a]s regards property, security consists in receiving no check, no shock, no derangement to the expectation founded on the laws, of enjoying such and such a portion of good'. ${ }^{67}$

This expectation of future use affects not just our ability to enjoy our property without inference by the state, but also impacts on the relationship between the owner $(A)$ and the non-owners $(B, C, D$ etc.). Convention theories suggest that it is the existence of laws that prevent the non-owners ( $B, C$ and D) from challenging A's ownership. Without respect for such conventions anarchy would arise: 'What must become of the world if such practices prevail? How could society subsist under such disorders?'68 Whilst such theories of property were originally developed in order to explain and justify political and social power structures, it seems undeniable that '[a]ll property references are, at some level, a statement about the social legitimacy attaching to the claim in question' ${ }^{69}$ Hence

\footnotetext{
${ }^{63}$ See, eg the work of James Penner and Henry E Smith in James Penner and Henry E Smith (eds), Philosophical Foundations of Property Law (Oxford, Oxford University Press, 2013).

${ }^{64}$ Kevin Gray \& Susan Francis Gray, Elements of Land Law $5^{\text {th }}$ edn (Oxford, Oxford University Press, 2009) 87, para 1.5.5.

65 David Hume, Enquiries Concerning Human Understanding and Concerning the Principles of Morals (first published 1739\&1740, OUP, 1990) 195.

66 Jeremy Bentham, Principles of the Civil Code Part I Ch VIII 112.

67 ibid, p. 113.

${ }^{68}$ David Hume, Enquiries 203.

${ }^{69}$ Gray \& Gray, Elements of Land Law 88, para 1.5.6.
} 
personal property rights could not exist without being both recognised by law and by our fellow human beings.

Hume's statement that property should devolve to children and relations was intended as a selfevident fact. No argument was made as to why this should be the case, and although as noted above some of the earlier cases talk in terms of natural law ${ }^{70}$ this has never been an established principle. Many of the contentious probate claims that come to court arise in situations where there are no close relatives or there has been a schism between the testator and the obvious close relative(s). In such situations in particular a consideration of these property theories will help to explain why there has been such an increase in contentious probate cases. For it is only if the cause behind the increase is understood that we can hope to counteract it.

If we start by considering the relationship between the owner of the property and the non-owners, the convention theories suggest that 'the limits of property "are the interfaces between accepted and unaccepted social claims". ${ }^{71}$ The convention principle relies on an expectation of reciprocity: the non-owners conclude that 'I will not steal from A because I also want A to respect my property'. Now let us consider what the difference would be if A was elderly. Although B would never steal from $A$, if an expectation is raised in B that A's property will become his on death then, despite the fact that B only has a mere spes in the property, he would develop his own expectation for the future use and enjoyment of that property on A's death. However, unbeknownst to B, C might also have had an expectation raised that the same property would become his on the death of $A$. C would likewise be developing his own plans for the property. Now, on the death of $A$, it is discovered that A made a recent will leaving everything to $D$. Thus both the appointed and disappointed beneficiaries view themselves as being entitled to the property and the situation is rather akin to three people who come across lost or abandoned property at the same time. Although $D$ should become the new owner, both $B$ and $C$ would regard themselves as having socially acceptable claims when judged against societal norms $\mathrm{s}^{72}$ and may feel justified in trying to actualise their expectation of forthcoming bounty by litigating the validity of the will itself. In the context of testamentary claims, property rights will be respected only if all affected parties believe the will truly reflects the testator's wishes.

Even before A's death, the imminence of their death and the ensuing need for A's property to change ownership can encourage all of A's friends and family to 'remind' A of their loyalty and

\footnotetext{
70 See nn 35-36 above.

${ }^{71}$ Gray \& Gray, Elements of Land Law 88, para 1.5.7, citing Dorman v Rodgers [1982] 148 CLR 365, 372 (Murphy J).

72 See nn 37-38 above.
} 
needs. The author does not wish to imply that all such conversations are intended to pressurise $A$, but there is undoubtedly a greater legitimacy in asking an elderly person what is going to happen to their property after their death and to then plead your case than there is in asking a fit and healthy younger person if you can have their property. The elderly property owner may appreciate advice and guidance on how best to dispose of their property (and be more receptive to it) but the danger is that they also feel pressured by those around them in a way that younger individual would not.

The hawk / dove analogy that is used in many more recent property theories ${ }^{73}$ starts to become particularly apt; the phrase 'vultures circling' encapsulates how those who were formerly doves can react when they can see the potential for future proprietary gain. Whilst such comments will not count as undue influence ${ }^{74}$ and therefore will not be enough to invalidate the will on this basis, the increased vulnerability and susceptibility of those with borderline capacity to be influenced by others may result in the testator's autonomy being undermined.

\section{Part IV - Capacity and Autonomy}

At the start of this paper the aim was to determine whether there could be a simple test for capacity that also preserves autonomy, and to answer this question, the relationship between autonomy and capacity needs to be considered. On a simplistic level, those with legal capacity have autonomy; they can decide when and how to do any lawful task. However, it has also been recognised that autonomy is not a simple concept. For example, John Coggon ${ }^{75}$ identified three different types of autonomy (ideal desire autonomy, best desire autonomy and current desire autonomy), with the difference between the three being determined by whether the person is acting in accordance with an objective standard of values (ideal desire autonomy), their own long term values and wishes (best desire autonomy), or the person's immediate wishes and inclinations (current desire autonomy).

This type of categorisation is very instructive when applied to the writing of a will. The 'rationality' test described above would seem to fit with the principles of 'best desire' autonomy described by Coggon in that a rational will is one that fits with the testator's long term values and beliefs as

\footnotetext{
${ }^{73}$ For example, the works of Robert Sugden, discussed in Carol M Rose, 'Psychologies of Property' in James Penner and Henry E Smith (eds), Philosophical Foundations of Property Law (Oxford, Oxford University Press, 2013)

${ }^{74} \mathrm{~A}$ good exposition of the fine line between undue influence and persuasion is found in Hall $v$ Hall, (1865-69) LR 1 P. \& D. 481: 'Persuasion, appeals to the affections or ties of kindred, to a sentiment of gratitude for past services, or pity for future destitution, or the like,-these are all legitimate, and may be fairly pressed on a testator. On the other hand, pressure of whatever character, whether acting on the fears or the hopes, if so exerted as to overpower the volition without convincing the judgment, is a species of restraint under which no valid will can be made.... In a word, a testator may be led but not driven; and his will must be the offspring of his own volition, and not the record of some one else's.' (Sir J P Wilde)

75 John Coggon, 'Varied and principled understandings of autonomy in English law: justifiable inconsistency or blinkered moralism?' (2007) 15 Health Care Analysis 235
} 
opposed to an embodiment of a person's immediate wishes without further reflection. Most testators (quite rightly) deliberate carefully on the terms of their will in order to ensure it properly reflects their wishes instead of acting on impulse without any detailed reflection.

If the Banks $v$ Goodfellow test is viewed as being not so much a test for capacity as a test for best desire autonomy, then the complexity criticism that is levelled at the test ${ }^{76}$ arguably has a benefit to the testator. A review of the authorities suggests that the courts have always been astute to the different levels of autonomy that may be exhibited in any individual and that the test can operate to assess cognitive function in detail.

As long ago as 1840, following an iteration of an earlier version of the Banks v Goodfellow test, the Privy Council gave the direction:

the question...is not whether Mr. Baker knew when he was giving all his property to his wife, and excluding all his other relations from any share in it, but whether he was at that time capable of recollecting who those relations were, of understanding their respective claims upon his regard and bounty, and of deliberately forming an intelligent purpose of excluding them from any share of his property (emphasis added). ${ }^{77}$

Thus it was not merely necessary for the testator to appreciate the moral claims he ought to consider, but also to have made a conscious decision to exclude. This change in emphasis usually comes to the fore in cases where there is a concern that the testator might have known the objects of their bounty, but may not have been in a position to appreciate the full effects of the new will. In Re Key there was no question of the testator failing to understand what he was doing. Instead, as Briggs J recognised, the impairment of his faculties was one that affected his mental energy and therefore the ability to make 'decisions of his $\mathrm{own}^{\text {178 }}$ - the inference being that the testator was lacking the required autonomy.

In Sharp $v$ Adam, the Court of Appeal focused especially on the final aspect of the Banks $v$ Goodfellow test, namely that that no disorder of his mind 'shall poison his affections, pervert his sense of right, or his will in disposing of his property' which was further expanded in Banks $v$ Goodfellow thus:

\footnotetext{
${ }^{76}$ The Banks v Goodfellow test is described as 'difficult to understand and apply' by the Law Commission http://www.lawcom.gov.uk/project/wills/.

77 Harwood v Baker (n 60) 290 (Erskine J).

${ }^{78}$ Re Key (Deceased) (n 18) [96] (Briggs J).
} 
If the human instincts and affections, or the moral sense, become perverted by mental disease; if insane suspicion, or aversion, take the place of natural affection... it is obvious that the condition of the testamentary power fails. ${ }^{79}$

Dementia affects sufferers in different ways, but studies of dementia patients show that 'aversions' are some of the most common cognitive changes. ${ }^{80}$ In Sharp $v$ Adam, the Banks $v$ Goodfellow test was applied to alterations that arise through age-related diseases; although it was acknowledged that the testator's cognition had not been affected, his 'mood' had ${ }^{81}$ and the conclusion of the Court of Appeal that he had lacked testamentary capacity at the time of making his final will was influenced by his decision to exclude his daughters entirely, instead of leaving them a small legacy as his solicitor suggested..$^{82}$

Therefore although revised wills can stem merely from the testator's own reflection upon their relationships and obligations in their later years, it is the diminishing ability to retain one's broader focus of all of the testamentary demands that can result in a testator crossing the imprecise divide'. ${ }^{83}$ The lack of strong presumptions in our current law enables it to reflect the subtleties involved, especially given the fact that many testators with signs of dementia may lose the ability to focus on their long term beliefs, and instead be driven by immediate desires and wishes. In such situations it is entirely appropriate for there to be a finding of lack of capacity, even though the testator may appear to understand what it is that they are doing.

It is, of course, vital that the courts do not measure wills against an objective standard of values, but a subjective analysis to determine whether the will accords with the long term wishes and desires of the testator can provide protection for vulnerable testators. Whenever a testator has demonstrated a relatively settled testamentary preference then it seems uncontroversial to say that a will that corresponds with this intention raises a presumption of capacity; ${ }^{84}$ in contrast a will that runs contrary to the testator's long term values and wishes suggests a lack of capacity. ${ }^{85}$

Unfortunately many testators do not have such clearly defined intentions, and all attempts to protect vulnerable testators must not inadvertently inhibit testamentary freedom, as to do so would

\footnotetext{
${ }^{79}$ Banks v Goodfellow (n 13), 565 (Cockburn CJ).

${ }^{80}$ O'Neill, N. and Peisah, C. Capacity and the Law (Sydney University Press, 2012) Ch 2

${ }^{81}$ Sharp v Adam (n 43) [93].

82 ibid, [94] (May LJ).

83 ibid.

${ }^{84}$ Bateman v Overy [2014] EWHC 432 (Ch D).

${ }^{85}$ Re Ritchie (Deceased) [2009] EWHC 709 (Ch D).
} 
put the testator in no better position than if a statutory will was made for them. ${ }^{86}$ Those accustomed to dealing with vulnerable clients know that it is often necessary to take instructions on multiple occasions to ensure that the testator's wishes are consistently held. ${ }^{87}$ It is argued that the complexities of the Banks $v$ Goodfellow test can be used to analyse a vulnerable testator's capacity with the care and consideration needed; the various strands of the test allow for a consideration of the type of autonomy the testator has demonstrated and this, coupled with the presumptions and counter-presumptions set out above, provides a mechanism whereby the courts can strive to balance the flexibility of testamentary freedom with the rigidity of testator protection.

The UK approach is in marked contrast to US law where there is not only a presumption of capacity, but a notable reluctance to declare that a testator lacked capacity even in what would seem the most obvious of cases. ${ }^{88}$ The level of testamentary capacity required in the US has been deliberately kept artificially low due to 'the American commitment to individual preference and autonomy's9 and the result of this is that the only effective challenge to a will is on the grounds of undue influence.

Although US authorities are often cited with approval, ${ }^{90}$ the common law test in England has seemingly always been alert to the influences of those who are close-by during the declining years of the testator. In the US the ideal of autonomy is seen as an absolute good, yet the presumption of capacity means that the testator could satisfy the capacity test even though they have only the lowest level of autonomy. It could be argued that the English emphasis on the additional capacity requirements of the ability to make decisions ${ }^{91}$ and to take control over the testamentary process is overly paternalistic, simply preventing the testator from doing something they might regret. However, if we recognise the particular vulnerability of testators to the claims of others and regard the Banks $v$ Goodfellow test as a test for best desire autonomy instead of a test for capacity a paternalistic approach can be justified as it ensures that the testator's decisions are supported and higher level autonomous decisions are respected.

If we shift our focus to the differing levels of autonomy then we can gain a better appreciation of the Banks $v$ Goodfellow test. Whilst it does not give the simple clarity that the presumption of capacity

\footnotetext{
${ }^{86}$ See, eg Dharamshi (Deceased), Re [2013] EWHC 3917 (Ch D) where an indecisive testator was found to have capacity as he knew what he wanted to achieve when making his final will.

${ }^{87}$ See, eg The Law Society Practice Note on meeting the needs of vulnerable clients (http://www.lawsociety.org.uk/support-services/advice/practice-notes/meeting-the-needs-of-vulnerableclients-july-2015/) includes (at para 4.6.1) the need to check for consistency in instructions.

${ }^{88}$ See, eg Re Dokken, 604 N.W.2d 487 (S.D. 2000) summarised in Lawrence A. Frolik 'The strange interplay of testamentary capacity and the doctrine of undue influence. Are we protecting older testators or overriding individual preferences?' (2001) International Journal of Law and Psychiatry Vol. 24, 253.

${ }^{89}$ Lawrence A. Frolik 'The strange interplay of testamentary capacity and the doctrine of undue influence' 255 .

${ }^{90}$ See, eg Re Walker (Deceased) (n 14) and Cowderoy v Cranfield (n 1).

${ }^{91}$ As expounded in Re Key (Deceased) (n 18) [96].
} 
in the MCA 2005 provides, the final element in particular allows the will drafter (and subsequently the courts if the validity of the will is disputed) to assess whether the quality of the testator's autonomy. As Coggon states, a person acting in accordance with their best desires may act against his immediate inclination yet the values behind the action are 'settled - although not necessarily permanent - and an agent recognises them as his values'. ${ }^{92}$ It is this sort of comprehension and understanding that the complexity of the Banks $v$ Goodfellow test enables the courts to pursue.

Any replacement for the Banks $v$ Goodfellow test therefore needs to be considered very carefully if we are not to lose this additional layer. A presumption of capacity would give certainty, but it would also presume only the most basic autonomy and that, this author feels, is a step too far. Such a presumption would also not make our law any more compliant with the CRPD as it would still embed a functional approach to capacity when we should instead be turning our attention to supported decision-making, whilst also adhering to the 'protectionist' requirements of the CRPD.

In order to comply better with the CRPD the Golden Rule mentioned above would seem to be an important element, especially with conditions such as dementia, the effects of which vary on a daily basis. A testator who might not have sufficient capacity on one visit might have improved cognition on a later visit, and the medical certificate of this cognition will help to ensure that the will is able to be proved. However, as simple as this rule may seem, it is not without its difficulties. First of all, solicitors are under a duty to act quickly when they receive instructions for a will, especially from an elderly testator. ${ }^{93}$ In such circumstances they may need to weigh their duty to comply with the Golden Rule against their duty to the client, and sometimes the latter duty may take precedence. ${ }^{94}$ Secondly, whilst many probate practitioners take the safe option of obtaining a medical certificate before preparing a will for any elderly testator, this can be seen as demeaning or even insulting ${ }^{95}$ and may deter the elderly from making a will at all - this would be a particularly unattractive side effect of a rule designed to reduce litigation and ensure that the testator's wishes are upheld.

It is worth noting that a significant number of the contentious probate cases arise where the wills are written by non-specialist probate practitioners. Under the Legal Services Act 2007 will-writing is not currently a reserved area and, despite calls from the Legal Services Board for it to become one, ${ }^{96}$

\footnotetext{
92 n 75, 241

${ }^{93}$ For an example of a breach of this duty and its consequences, see White $v$ Jones [1995] 2 AC 207, [1995] 2 WLR $187(\mathrm{HL})$.

${ }^{94} \mathrm{See}$, eg the comments of Norris J in Wharton v Bancroft [2011] EWHC 3250 (Ch D), [2012] WTLR 693.

95 See Hill v Fellowes Solicitors LLP [2011] EWHC 61 (QB), (2011) 118 BMLR 122 [77] (Sharp J).

96 Two Legal Services Board Consultations from 2012, both entitled 'Enhancing consumer protection, reducing regulatory restrictions: will-writing, probate and estate administration activities' concluded that will writing should be added to the list of reserved activities under s 12 Legal Services Act 2007.
} 
this seems unlikely to happen. However, if those at risk of losing their autonomy and their capacity are to be supported in their decisions as to where their property goes on their death it is imperative that the person making the will recognises the dangers. If we really want to support the decisionmaking powers of the elderly and those with impaired capacity, yet also reduce litigation, then maybe we need to say that this is specialist work for specialist lawyers. This would probably not increase the numbers of those who make wills, but it would hopefully give everyone more confidence in the outcome.

Unfortunately, the author acknowledges that the harder it is perceived to be to make a will, the fewer people will do it and the distribution of property on intestacy rules will most likely be even more contrary to the wishes of the deceased than any voluntary will. However, simple wills drafted by those who do not understand the complexities of issues of capacity, or the risks of litigation are equally not ensuring that the deceased's wishes are carried out - due to the costs of litigation it is far worse to have an invalid will than to have no will at all. Furthermore, the mere fact that we permit such wills potentially means that we are in breach of our 'protectionist' obligations under the CRPD.

Even more unpalatable alternatives would be to consider the introduction of forced heirship rules, or alternatively to introduce a limited presumption of capacity with certain common testamentary patterns, but this would impact on non-standard families; given the on-going battle between the Law Commission and the Government regarding rights of cohabitees, it would seem foolhardy to introduce another potential battleground. We must accept and embrace the fact that many people have genuine reasons for wishing to direct their property to some particular friends or relatives at the expense of others.

\section{Conclusions}

The precise identification of testamentary capacity will always prove difficult; our current understanding of mental health means that we are now much more alert to differing levels of capacity, and we are reluctant to deny capacity to those who have been self-sufficient for many years. However a presumption of capacity would put the vulnerable at risk of succumbing to the influence of others.

Despite the lack of certainty that the existing common law test brings, its complexity enables the evidence to be analysed to establish each testator's capabilities and vulnerabilities on a case-by-case basis. In the more complex and borderline cases the Banks $v$ Goodfellow test can be used to protect the vulnerable by helping to identify the point at which the testator became overly susceptible to persuasion or moves away from best desire autonomy to current desire autonomy. Clearly it would 
be better for this sifting and analysis of the evidence to be carried out before, not after, the testator's death.

Notwithstanding the principle of testamentary freedom, the underlying social justification for, and acceptance of, testamentary challenges indicates that a certain amount of litigation is inevitable. However, it may be possible to reduce the number of claims being dealt with by the courts if we acknowledge that the complexities of testamentary capacity mean it should be handled by specialists in the field. This gives us the best chance of supporting the testator in his decision making on a case-by-case basis. The challenge for the Law Commission seems not so much to aim for simplicity and certainty, but to create a rich test of capacity that acknowledges the subtleties of human nature and relationships, yet provides scope for supporting the higher level autonomy of those nearing the end of their lives. 